\title{
GALERY WALK DALAM AKTIVITAS BELAJAR: PENELITIAN TINDAKAN KELAS DI MADRASAH IBTIDAIYAH
}

\author{
Wawan Setiawan ${ }^{1}$, Hani Nurasiah ${ }^{1}$ \\ ${ }^{1}$ Jurusan Pendidikan Guru Madrasah Ibtidaiyah, UIN Sunan Gunung Djati, Bandung, Indonesia \\ haninurasiah@gmail.com
}

Naskah diterima: 25 Desember, 2017, direvisi: 1 januari, 2018, diterbitkan: 31 Maret, 2018

\begin{abstract}
This study aims to determine the effect of the application of the Gallery Walk model to improve student learning activities on art subjects of ornamental motifs in 5th grade MI Al-Manar Cianjur. This research uses classroom action research method consisting of two cycles, each cycle there are two actions with the stages of activity planning, action, observation, and reflection. The results of the study: for cycle 1 and cycle 2 there are two actions, then the results of both actions are accumulated. Based on the data analysis, the result of the research shows that there is influence from the application of Gallery Walk method to the improvement of student learning activity seen from the percentage of measurement of pre cyclical learning activity of $28.07 \%$ with low criterion. Cycle 1 of 62,6\% with a good criterion, while cycle 2 equal to 83,3\% with a very good criterion. Based on the findings it can be seen that the implementation of Gallery Walk can improve student learning activities on subjects SBK subject of decorative motif type.
\end{abstract}

Keywords: gallery walk, student learning activities, model of teaching

\begin{abstract}
ABSTRAK
Penelitian ini bertujuan untuk mengetahui pengaruh penerapan model Gallery Walk untuk meningkatkan aktivitas belajar siswa pada mata pelajaran SBK pokok bahasan jenis motif hias di kelas V MI Al-Manar Kabupaten Cianjur. Jenis penelitian ini menggunakan metode penelitian tindakan kelas (PTK) yang terdiri dari 2 siklus, setiap siklus terdapat dua tindakan dengan tahapan kegiatan perencanaan, melakukan tindakan, observasi serta refleksi. Hasil penelitian: untuk siklus 1 dan siklus 2 terdapat dua tindakan, kemudian hasil dari kedua tindakan tersebut diakumulasikan. Berdasarkan analisis data diperoleh hasil penelitian yang menunjukan bahwa ada pengaruh dari penerapan metode Gallery Walk terhadap meningkatnya aktivitas belajar siswa dilihat dari persentase pengukuran aktivitas belajar siswa pra sikus sebesar $28,07 \%$ dengan kriteria kurang. Siklus 1 sebesar 62,6\% dengan kriteria baik, sedangkan siklus 2 sebesar 83,3\% dengan kriteria sangat baik. Berdasarkan temuan-temuan tersebut dapat diketahui bahwa penerapan Gallery Walk dapat meningkatkan aktivitas belajar siswa pada mata pelajaran SBK pokok bahasan jenis motif hias.
\end{abstract}

Kata Kunci: aktivitas belajar siswa, gallery walk, model pembelajaran

\section{PENDAHULUAN}

Kamus Besar Bahasa Indonesia menjelaskan hal yang berkaitan dengan istilah pendidikan, sebagai berikut: Pendidikan berasal dari kata dasar didik, dan diberi awalan men, menjadi mendidik, yaitu kata kerja yang artinya memelihara dan memberi latihan (ajaran) pendidikan sebagai kata benda berarti proses perubahan sikap dan tingkah laku seseorang atau kelompok orang untuk mendewasakan manusia upaya pengejaran dan latihan (Yahya, 2010, hlm. 7).

Dalam kegiatan pembelajaran, terdapat dua kegiatan yang sinergis, yakni guru mengajar dan siswa belajar. Guru mengajarkan bagaimana siswa harus belajar. Sementara 
siswa belajar bagaimana seharusnya belajar melalui berbagai pengalaman belajar hingga terjadi perubahan dalam dirinya dari aspek kognitif, psikomotor dan atau afektif. Karena itu guru harus merancang kegiatan pembelajaran yang memungkinkan siswa melakukan kegiatan belajar secara aktif, baik fisik maupun mental. Siswa akan belajar secara aktif kalau rancangan pembelajaran yang disusun guru mengharuskan siswa, baik secara sukarela maupun terpaksa. Dengan demikian ada korelasi signifikan antara kegiatan mengajar guru dan kegiatan belajar siswa. Mengaktifkan kegiatan belajar siswa berarti menuntut kreativitas dan kemampuan guru dalam merancang dan melaksanakan kegiatan pembelajaran (Marno dkk, 2009, hlm. 149).

Mata pelajaran Seni Budaya dan Keterampilan (SBK) di SD/MI berusaha memberikan wawasan secara komprehensif mengenai keunikan, kebermaknaan, dan kebermanfaatan terhadap kebutuhan perkembangan peserta didik, yang terletak pada pemberian pengalaman estetik dalam bentuk kegiatan berkreasi dan berapresiasi dalam kegiatan pembelajaran di sekolah.

Melalui studi pendahuluan yang dilakukan terhadap siswa kelas V di MI Al-Manar Cianjur dengan mengamati langsung ketika proses pembelajaran Seni Budaya dan Keterampilan (SBK), terlihat guru menyampaikan materi hanya dengan menggunakan metode ceramah dan pemberian tugas pada akhir pembelajaran. Selain itu, terdapat siswa yang kurang antusias selama kegiatan pembelajaran berlangsung dan beberapa siswa yang lain tidak fokus terhadap materi yang disampaikan oleh guru di kelas. Melihat fenomena tersebut, aktifitas belajar siswa menjadi kurang kondusif dan tidak sesuai dengan tujuan yang diharapkan oleh guru. Hal tersebut mengakibatkan hasil belajar siswa yang kurang maksimal, sekitar $40 \%$ dari jumlah keseluruhan siswa belum memenuhi kriteria ketuntasan minimal dari hasil penilaian hasil belajar pada mata pelajaran Seni Budaya dan Keterampilan di kelas V MI Al-Manar Cianjur.

Berdasarkan permasalahan di atas perlu adanya penerapan model dalam meningkatkan aktivitas belajar siswa selama pembelajaran. Dalam hal ini Model Gallery Walk dapat digunakan sebagai penunjuang dalam meningkatkan aktivitas belajar siswa. Model Gallery walk merupakan suatu teknik diskusi yang membuat siswa keluar dari tempat duduk mereka dan aktif dalam mengumpulkan konsep kalimat penting, menulis, dan berbicara di depan umum (Francek 2006) (Widarti dkk, 2013, p. 11). Keunggulan pembelajaran ini siswa dapat berpartisifasi aktif, saling belajar dari teman, pembelajaran menjadi menyenangkan sehingga siswa menjadi termotivasi yang mengakibatkan aktivitas belajar siswa menjadi lebih baik. Menurut Silberman (2009,p.264), yang menyebutnya dengan istilah Galeri Belajar, "merupakan suatu cara untuk menilai dan merayakan apa yang telah peserta didik pelajari setelah rangkaian pelajaran studi”.

Adapun langkah-langkah penerapan metode Gallery Walk (Tim Teaching: 2011) :

1) Peserta dibagi dalam beberapa kelompok.

2) Kelompok diberi kertas plano/ flip chart.

3) Tentukan topik/tema pelajaran.

4) Hasil kerja kelompok ditempel di dinding.

5) Masing-masing kelompok berputar mengamati hasil kerja kelompok lain.

6) Salah satu wakil kelompok menjawab setiap apa yang ditanyakan oleh kelompok lain.

7) Koreksi bersama-sama.

8) Klarifikasi dan penyimpulan.

Ditinjau dari langkah-langkah di atas penulis bependapat bahwa, model Gallery Walk mampu meningkatkan antusiasme, keaktifan dan respon dalam pembelajaran. Maka dari itu sangat cocok sekali digunakan untuk anak Madrasah Ibtidaiyah atau sekolah dasar dalam aktifitas pembelajaran. 
Sehingga menurut Uno dkk (2013, hlm. 102), Model Gallery Walk ini disebut dengan istilah metode kunjung karya. Metode yang mendorong siswa mengetahui apa yang telah dikerjakan temanya. Dimana kegiatannya saling melihat hasil karya orang lain untuk belajar bertanya, memberikan komentar dan saran. Sementara pihak yang dikunjungi menjawab, menanggapi komentar dan saran secara produktif. Dalam kegiatan ini, siswa bergerak mengamati hasil karya-karya mereka. Metode ini mempunyai tujuan agar masingmasing anggota kelompok mendapat kesempatan untuk memberikan kontribusi mereka dan mendengarkan pandangan serta pemikiran anggota lainnya. sehingga Gallery Walk dirasa dapat digunakan sebagai salah satu model yang dapat digunakan untuk meningkatkan aktifitas belajar siswa.

Melihat karakteristik siswa MI yang aktif dan cepat bosan, maka diperlukan model pembelajaran yang dapat menarik perhatian siswa dalam kegiatan pembelajaran dikelas.

Model Gallery Walk ini dapat digunakan dalam materi seni rupa jenis motif hias yang berhubungan dengan gambar, lambang, grafis maupun gabungan yang berbentuk dua dimensi. Harapan dengan penggunaan model Gallery Walk ini siswa dapat lebih antusias dalam pembelajaran di kelas serta siswa menjadi lebih aktif.

Aspek yang perlu diperhatikan dalam aktivitas belajar, menurut Diedrich (Hamalik, 2010, hlm. 172)

1. Kegiatan-kegiatan visual (Visual Activities),

Membaca, melihat gambar-gambar, mengamati eksperimen, demonstrasi, pameran, dan mengamati orang lain bekerja atau bermain.

2. Kegiatan-kegiatan lisan (Oral activities)

Mengemukakan suatu fakta atau prinsip, menghubungkan suatu kejadian, mengajukan pertanyaan, memberi saran, mengemukakan pendapat, wawancara, diskusi, dan interupsi.

3. Kegiatan-kegiatan mendengarkan (Listening Activities)

Mendengarkan penyajian bahan, mendengarkan percakapan atau diskusi kelompok, mendengarkan suatu permainan, mengengarkan radio.

4. Kegiatan-kegiatan menulis (Writing Activities)

Menulis cerita, menulis laporan, memeriksa karangan, bahan-bahan kopi, membuat rangkuman, mengerjakan tes, dan mengisi angket.

5. Kegiatan-kegiatan menggambar (Drawing Activities)

Menggambar, membuat grafik, chart, diagram peta, dan pola.

6. Kegiatan-kegiatan mental (Mental Activities)

Merenungkan, mengingat, memecahkan masalah, menganalisis, faktor-faktor, melihat, hubungan-hubungan, dan membuat keputusan.

7. Kegiatan-kegiatan emosional (Emotional Activities)

Minat, membedakan, berani, tenang, dan lain-lain. Kegiatan-kegiatan dalam kelompok ini terdapat dalam semua jenis kegiatan dan overlap.

Aktivitas belajar siswa begitu mempengaruhi terhadap prestasi belajar siswa dalam membuat dan mempelajari jenis motif hias yang sesuai dengan tujuan pembelajaran. Jenis motif hias termasuk kedalam aspek seni rupa dalam mata pelajaran Seni Budaya dan Keterampilan (SBK). Pembelajaran Seni Budaya dan Keterampilan, muatan seni budaya dan keterampilan sebagaimana yang diamanatkan dalam Peraturan Pemerintah Republik Indonesia Nomor 19 tahun 2005 tentang Standar Nasional Pendidikan tidak hanya terdapat dalam satu mata pelajaran karena budaya itu sendiri meliputi segala aspek kehidupan. Dalam mata pelajaran Seni Budaya dan Keterampilan, aspek budaya tidak dibahas secara tersendiri tetapi terintegrasi dengan seni. Karena itu, mata pelajaran Seni Budaya dan Keterampilan pada dasarnya merupakan pendidikan seni yang berbasis budaya.

Sesuai dengan Kurikulum Tingkat satuan Pendidikan, Pendidikan Seni Budaya dan Keterampilan memiliki sifat multilingual, multidimensional, dan multikultural. Hal ini 
ditegaskan dalam Kurikulum Berbasis Kompetensi (KBK) dan Kurikulum Tingkat satuan Pendidikan (KTSP) (Bandi, 2009, hlm. 20).

Menurut Arinil (2011) dalam Naisah (2013, hlm. 6) mata pelajaran Seni Budaya dan Keterampilan meliputi aspek-aspek sebagai berikut: Seni rupa, mencakup pengetahuan, keterampilan, dan nilai dalam menghasilkan karya seni berupa lukisan, patung, ukiran, cetakmencetak, dan sebagainya; Seni musik, mencakup kemampuan untuk menguasai olah vokal, memainkan alat musik, apresiasi karya musik; Seni tari, mencakup keterampilan gerak berdasarkan olah tubuh dengan dan tanpa rangsangan bunyi, apresiasi terhadap gerak tari; Seni drama, mencakup keterampilan pementasan dengan memadukan seni musik, seni tari dan peran; Keterampilan, mencakup segala aspek kecakapan hidup (life skills) yang meliputi keterampilan personal, keterampilan sosial, keterampilan vokasional dan keterampilan akademik. Di antara keempat bidang seni yang ditawarkan, minimal diajarkan satu bidang seni sesuai dengan kemampuan sumberdaya manusia serta fasilitas yang tersedia. Mata pelajaran Seni Budaya dan Keterampilan bertujuan agar peserta didik memiliki kemampuan sebagai berikut yaitu, memahami konsep dan pentingnya seni budaya dan keterampilan, menampilkan sikap apresiasi terhadap seni budaya dan keterampilan, menampilkan kreativitas melalui seni budaya dan keterampilan, menampilkan peran serta dalam seni budaya dan keterampilan dalam tingkat lokal, regional, maupun global.

Dalam materi jenis motif hias, aspek yang ditekankan lebih kepada daya imajinasi dan kreatifitas siswa dalam menuangkan ide atau gagasannya kedalam sebuah gambar maupun skema yang nantinya akan dipajang untuk dipresentasikan dengan cara pameran. Dalam penerapan model Gallery Walk siswa tidak akan merasa jenuh karena gambargambar yang dipaparkan sangat menarik dan komunikatif. Dalam penerapan model Gallery Walk ini diharapkan mampu meningkatkan aktivitas belajar siswa di kelas V MI Al-Manar Kabupaten Cianjur.

\section{METODOLOGI}

Medote penelitian yang dilaksanakan adalah penelitian tindakan kelas, merupakan bentuk penelitian tindakan yang diterapkan dalam aktivitas pembelajaran di kelas. Ciri khusus PTK adalah adanya tindakan nyata yang dilakukan sebagai bagian dari kegiatan penelitian dalam rangka memecahkan masalah penelitian tindakan kelas (PTK) ini akan dilaksanakan sebanyak 2 siklus. Setiap siklus terdiri dari 4 tahap perencanaan, pelaksanaan, observasi, dan refleksi.Menurut Salahuddin (2015, hlm. 26) dalam bidang pendidikan, khususnya kegiatan pembelajaran, penelitian tindakan kelas berkembang sebagai penelitian terapan. Penelitian tindakan kelas sangat bermanfaat bagi guru untuk meningkatkan mutu proses dan hasil pembelajaran dikelas. Dengan melaksanakan tahaptahap penelitian tindakan kelas, guru dapat menemukan solusi dari masalah yang timbul dikelasnya, dengan menerapkan berbagai ragam teori dan teknik pembelajaran yang relevan secara kreatif. Selain itu, sebagai penelitian terapan, di samping melaksanakan tugas mengajar dikelas, guru tidak harus meninggalkan siswanya. Dengan demikian, penelitian tindakan kelas merupakan penelitian yang mengangkat permasalahan aktual yang dihadapi oleh guru dilapangan.

Jenis data yang digunakan dalam penelitian ini adalah data kualitatif dan data kuantitatif. Menurut Sugiyono (2012, p.13) data kualitatif lebih bersifat deskriptif. Data yang terkumpul berbentuk kata-kata atau gambar, sehingga tidak menekankan pada angka. Penelitian kualitatif lebih menekankan pada proses daripada produk atau outcome. Contoh data kualitatif: siswa berdiskusi secara aktif, perhatian siswa terhadap mata pelajaran SBK rendah, dan rata-rata skor UAS semester ini naik. Sementara, data kuantitatif adalah data kuantitatif merupakan data yang berupa angka atau bilangan. 
Penelitian berlangsung dari 17 Februari - 30 Maret 2016. Dalam penelitian ini terdapat lima kali pertemuan setiap tindakannya.pada pra siklus dilaksanakan pada tanggal 17 Februari 2016 pukul 11.00 - 12.10 WIB. Pada siklus 1 tindakan 1 dilaksanakan pada tanggal 2 Maret 2016 pukul 11.00-12.10 WIB. Pada siklus 1 tindakan 2 dilaksanakan pada tanggal 23 Maret 2016 pukul 11.00 - 12.10 WIB. Pada siklus 2 tindakan 1 dilaksanakan pada tanggal 26 Maret pukul $10.00-11.10$ WIB. Siklus 2 tindakan 2 dilaksanakan pada tanggal 30 Maret 2016 pukul 10.00-11.10. lokasi penelitian bertempat di MI Al-Manar Jl. Mariwati KM.03, Kp. Cibadak RT 02 RW.01 Desa Sukanagalih Kecamatan Pacet Kabupaten Cianjur Propinsi Jawa Barat kode pos 43253.

Subjek dalam penelitian ini adalah siswa kelas V MI Al-Manar Kabupaten Cianjur dengan jumlah siswa sebanyak 30 siswa terdiri dari 15 orang siswa laki-laki dan 15 orang siswa perempuan.

Sebagai upaya mencari pembuktian dan solusi dari masalah yang diangkat dalam penelitian ini, peneliti telah menentukan dan merancang desain penelitian dengan desain Penelitian Tindakan Kelas (PTK) yang ditandai dengan adanya siklus, adapun dalam penelitian ini terdiri atas 2 siklus. Setiap siklus terdiri atas perencanaan, pelaksanaan, pengamatan dan refleksi.

1. Perencanaan

Kegiatan yang dilakukan anatara lain :

a. Menyusun rencana pembelajaran tentang standar kompetensi, dan setiap pertemuan satu rencana pelaksanaan pembelajaran.

b. Mempersiapkan media model pembelajaran Gallery Walk yang terkait dengan materi Jenis Motif hias.

c. Menyusun lembar observasi aktivitas.

2. Pelaksanaan tindakan

Kegiatan yang dilakukan adalah memberikan gambaran tentang proses pembelajaran yang akan dilakukan dengan melakukan tujuan pembelajaran yang ingin dicapai. Setelah itu dibuat beberapa kelompok supaya proses pembelajaran lebih mudah, Setelah kelompok dibuat setiap kelompok diberi kertas plano/flip chart, guru menjelaskan secara singkat materi pembelajaran yang akan di sampaikan sesuai dengan tema, hasil kerja kelompok di tempel di dinding, masing-masing kelompok berputar mengamati hasil kerja kelompok lain, salah satu wakil kelompok menjawab setiap apa yang ditanyakan oleh kelompok lain, guru dan murid koreksi bersama-sama dan buat kesimpulan dibantu dengan guru.

3. Observasi

Kegiatan yang dilakukan adalah mengamati kegiatan yang dilakukan siswa selama pelaksanaan pembelajaran dengan menggunakan model Gallery Walk. Dengan cara mengisi lembar observasi motivasi siswa dan guru saat pelaksanaan pembelajaran.

4. Refleksi

Kegiatan yang dilakukan adalah merefleksikan kegiatan yang telah dilakukan siswa selama pelaksanaan pembelajaran apakah siswa berperan secara aktif dalam pembelajaran, apakah proses pembelajaran tidak menjenuhkan, apakah motivasi siswa semakin bertambah dengan menggunakan model Gallery Walk pada mata pelajaran Seni Budaya dan Keterampilan (SBK) Materi Jenis Motif hias. Hal ini dimaksudkan agar hasil refleksi ini dapat berguna bagi siswa maupun guru di masa yang akan datang.

Dalam teknik pengumpulan data menggunakan teknik non tes, yaitu observasi dan dokumentasi. Observasi (observation) atau pengamatan merupakan suatu teknik atau cara mengumpulkan data dengan jalan mengadakan pengamatan terhadap kegiatan yang sedang berlangsung (Sukmadinata 2012, p.220). Observasi dilakukan untuk mengamati aktivitas siswa dan guru pada saat proses pembelajaran. Alat bantu yang dipakai berupa lembar observasi yang dibuat berdasarkan aspek-aspek aktivitas yang hendak diobservasi. Melalui teknik ini juga penulis akan mencari informasi dan data yang faktual tetang peningkatan 
aktivitas siswa pada mata pelajaran seni budaya dan keterampilan, keadaan sekolah, keadaan guru dan siswa, yang khususnya siswa kelas V MI Al-Manar Kabupaten Cianjur. Kamus Umum Bahasa Indonesia menyebutkan dokumen adalah sesuatu yang tertulis atau tercetak yang dapat dipergunakan sebagai bukti atau keterangan. Dokumentasi ini dilakukan untuk membandingkan seluruh kegiatan penelitian atau beberapa kejadian penting dalam penenlitian yang dapat memberikan informasi dan penguatan data yang diperoleh, dokumentasi ini menggunakan kamera foto sehingga dokumentasi ini berupa foto-foto kegiatan belajar mengajar ataupun hal lainya.

Teknik Analisis Data dalam penelitian ini, sebagai berikut :

1. Untuk menjawab rumusan masalah nomor satu bagaimana aktivitas belajar siswa sebelum penerapan model Gallery Walk pada mata pelajaran seni budaya dan keterampilan pokok bahasan jenis motif hias kelas V MI Al-Manar Kabupaten Cianjur dengan menggunakan lembar observasi aktivitas siswa dan guru.

2. Untuk mengetahui jawaban rumusan masalah nomor dua bagaimana penerapan model Gallery Walk pada mata pelajaran seni budaya dan keterampilan pokok bahasan jenis motif hias kelas V MI Al-Manar Kabupaten Cianjur maka dilakukan observasi oleh satu orang observer mengisi lembar observasi dan melakukan dokumentasi.

3. Untuk mengetahui jawaban rumusan masalah nomor tiga bagaimana aktivitas belajar siswa sesudah penerapan model Gallery Walk pada mata pelajaran seni budaya dan keterampilan pokok bahasan jenis motif hias kelas V MI Al-Manar Kabupaten Cianjur pada setiap siklus, dengan menggunakan lembar observasi aktivitas siswa dan guru.

Data yang dianalisis meliputi data kuantitatif, dan data kualitatif. Analisis data setelah masa pengumpulan data selesai ketika setiap siklus sudah melakukan proses pembelajaran lalu dilanjutkan dengan evaluasi lembar observasi adapun langkah-langkah analisisnya sebagai berikut.

1. Mengumpulkan data lembar observasi.

2. Mengolah data.

3. Menyusun simpulan sementara.

4. Di akhir siklus Penarikan simpulkan akhir.

Teknik analisis lembar observasi digunakan untuk mengetahui peningkatan aktivitas belajar siswa pada tiap siklus dan akhir siklus dapat dilihat dari presentase rata-rata aktivitas belajar siswa. Hasil yang dapat di hitung dalam menjumlahkan nilai seluruh siswa yang didapat untuk setiap aktivitas tersebut kemudian hitung rata-ratanya.

$$
\begin{aligned}
& \text { Aktivitas siswa dalam KBM }=\frac{\text { jumlah aktivitas setiap siswa }}{\text { Jumlah Intem Soal } x \text { Skor Maksimal }} \times 100 \\
& \text { Aktivitas guru dalam KBM }=\frac{\text { jumlah aktivitas guru }}{\text { Jumlah Intem Soal }} \times 100
\end{aligned}
$$

(Susilawati, 2010, hlm. 95)

Tabel 1. Kriteria Keterlaksanaan Aktivitas Pembelajaran

\begin{tabular}{|c|c|c|}
\hline No & Presentase Keterlaksanaan & Kategori \\
\hline 1 & $0-19$ & Sangat kurang \\
\hline 2 & $20-39$ & Kurang \\
\hline 3 & $40-59$ & Sedang \\
\hline 4 & $60-79$ & Baik \\
\hline 5 & $80-100$ & Sangat Baik \\
\hline
\end{tabular}

(Purwanto, 2006, hlm. 102) 


\section{HASIL DAN DISKUSI}

a. Aktivitas Belajar Siswa Pada Mata Pelajaran SBK Sebelum Menggunakan Model Gallery Walk

Jenis Motif hias pada mata pelajaran seni budaya dan keterampilan (SBK) di kelas V MI Al-Manar sebelum menggunakan model Gallery Walk yaitu dilaksanakan pada pra siklus yaitu pembelajaran masih konvensional, menggunakan metode ceramah, ketika siswa diarahkan untuk membuat produk, siswa membuat pola tameng jenis motif hias. Adapun aktivitas siswa pada pra siklus, siswa yang memulai berkembang hanya sebesar $28,07 \%$ dengan krieria kurang artinya masih banyak siswa yang tidak aktif dalam pembelajaran khususnya pada materi jenis motif hias.

Banyak siswa yang kurang dalam aktivitas belajar, terutama pada saat membuat jenis motif hias berupa tameng, bahan yang digunakan hanya bahan sederhana tidak ada bahan lainnya, imajinasi yang belum meluas, masih bingung dengan materi jenis motif hias, tidak percaya diri dengan kreatifitas yang dibuatnya, masih berpikir abstrak tidak kongkrit, karena tidak adanya contoh jenis motif hias hanya menggunakan buku paket saja.

b. Aktivitas Belajar Siswa Pada Mata Pelajaran SBK Dengan Menggunakan Model Gallery Walk Pada Setiap Siklusnya

Berdasarkan tabel 2 hasil aktivitas belajar siswa dalam membuat jenis motif hias mengalami peningkatan pada setiap siklunya, adapun peningkatannya meliputi pra siklus 28,07\% (Kurang), Siklus I 62,6 ( Baik), dan Siklus II 83,3\% (Sangat Baik)

Tabel 2 Peningkatan Aktivitas Siswa Pada Setiap siklusnya

\begin{tabular}{|c|c|c|c|}
\hline \multirow{2}{*}{ No. } & \multicolumn{3}{|c|}{ Aktivitas Siswa } \\
\cline { 2 - 4 } & Pra Siklus & Siklus I & Siklus II \\
\hline 1 & 842 & 1878 & 2499 \\
\hline 2 & $28,07 \%$ & $62,6 \%$ & $83,3 \%$ \\
\hline
\end{tabular}

Peningkatan tersebut terihat dari persiapan bahan dan kelengkapan alat lebih tersusun dan terencana dibandingkan dalam prasiklus, siswa berperan aktif dalam mebuat jenis motif hias, dan percaya diri dengan hasil yang dibuatnya sendiri, dalam pelaksananaan Gallery Walk siswa tidak malu untuk memajang hasil karyanya di stan yang telah disediakan di dalam kelas, siswa juga tidak malu bertanya kepada teman sebayanya dan siswa tidak terlihat jenuh tetapi terlihat senang.

Hasil presentase di atas mampu membuktikan bahwa dengan menggunakan model Gallery Walk dapat meningkatkan aktivitas belajar siswa pada mata pelajaran Seni Budaya dan Keterampilan (SBK) pokok bahasan jenis motif hias di kelas VMI Al-Manar. Sehingga hipotesis dapat diterima.

Peningkatan Aktivitas siswa kelas V MI Al-Manar Kabupetan Cianjur dapat dilihat berdasarkan grafik sebagai berikut: 


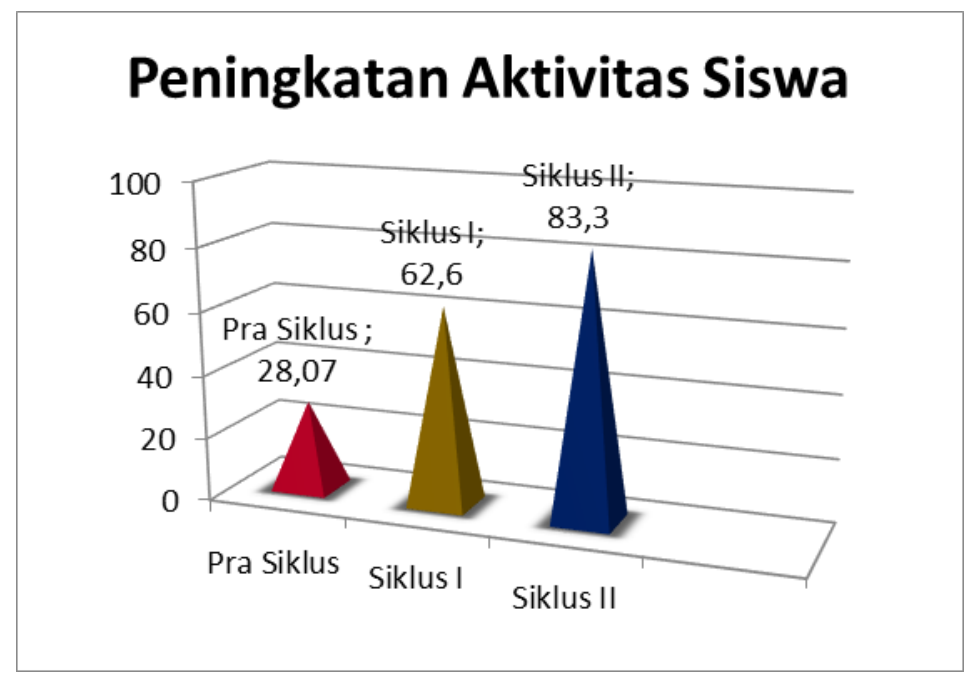

Grafik 1. Peningkatan Aktivitas Siswa Setiap Siklus

c. Proses penerapan model Gallery Walk pada mata pelajaran SBK

1) Aktivitas Siswa

Proses penerapan model Gallery Walk pada mata pelajaran Seni Budaya dan Keterampilan di kelas V Mi Al-Manar pada setiap siklusnya mengalami peningkatan yang signifikan, hal tersebut dapat dibuktikan berdasarkan 6 tabel dari hasil observasi aktivitas siswa mengenai jenis motif hias mengalami peningkatan pada setiap tindakan dalam setiap siklusnya, adapun peningkatan meliputi pra siklus 28,07 (kurang), siklus I 62,6\% (baik), dan siklus II 83,3\% (sangat baik).

Daryanto (2010, hlm. 165) dalam proses belajar mengajar, guru perlu menimbulkan aktivitas siswa dalam berpikir maupun berbuat. Terbukti dan pembelajaran SBK, siswa mampu mengikuti pembelajaran dengan baik, dari setiap siklusnya aktivitas siswa mengalami perubahan, yang pada pra siklus ada beberapa siswa yang kurang aktif dan cenderung pendiam, pada siklus-siklus berikutnya siswa tersebut mampu aktif, berani bertanya, dan menyampaikan gagasannya.. Maka dari itu, aktivitas dalam pembelajaran SBK dengan menggunakan model Gallery Walk mengalami peningkatan dibandingkan dengan aktivitas belajar siswa pada pra siklus yang tidak menggunakan model Gallery Walk.

Tabel 3. Peningkatan Aktivitas Belajar Siswa Pada Setiap Siklusnya

\begin{tabular}{|c|c|c|c|c|c|}
\hline \multirow{2}{*}{ No } & \multicolumn{5}{|c|}{ Aktivitas Siswa } \\
\cline { 3 - 6 } & \multirow{2}{*}{ Pra Siklus } & \multicolumn{2}{|c|}{ Siklus I } & \multicolumn{2}{c|}{ Siklus II } \\
\cline { 3 - 6 } 1 & \multirow{2}{*}{842} & 1 & 2 & 1 & 2 \\
\hline 2 & & $56,73 \%$ & $68,47 \%$ & $77,8 \%$ & $88,8 \%$ \\
\hline 3 & $28,07 \%$ & \multicolumn{2}{|c|}{$62,2 \%$} & \multicolumn{2}{c|}{$83,3 \%$} \\
\hline
\end{tabular}

Adapun untuk memperjelas perbandingan hasil observasi pada setiap siklusnya dapat dilihat pada grafik berikut ini. 


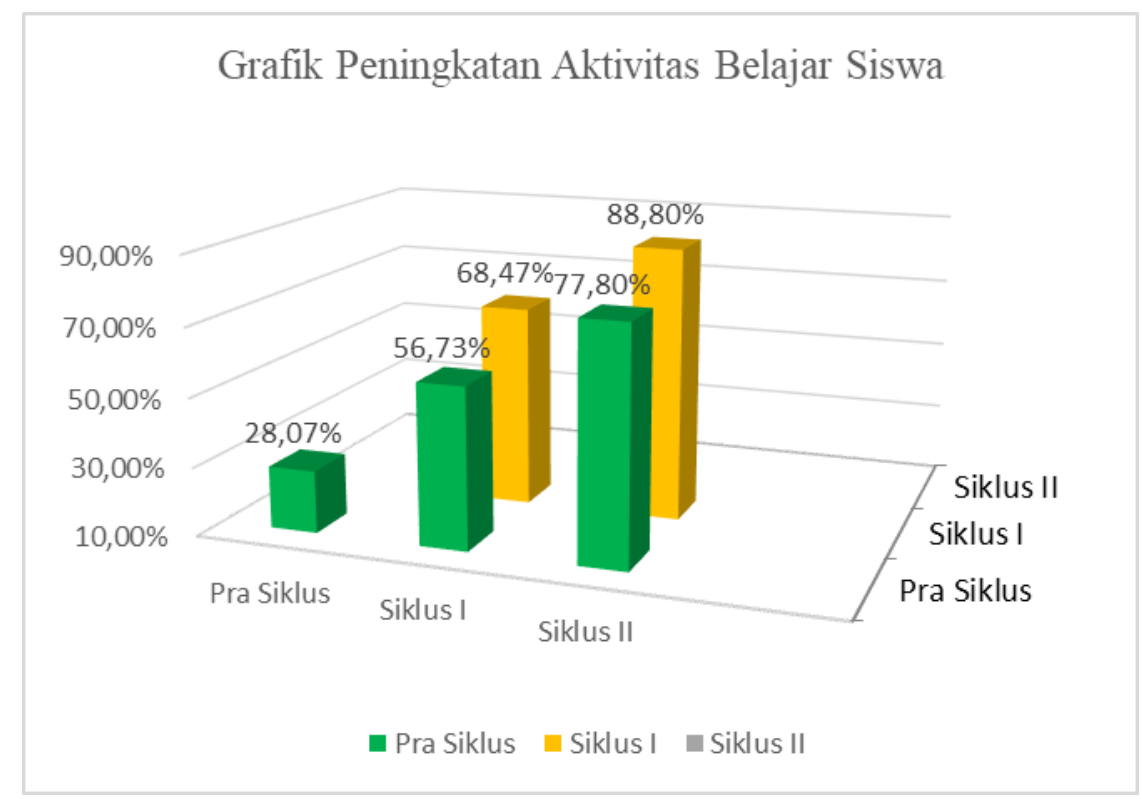

Grafik 2. Peningkatan Aktivitas Belajar Siswa

Berdasarkan gambar 2 grafik peningkatan aktivitas dapat diketahui bahwa hasil observasi aktivitas belajar siswa mengalami perbaikan dan peningkatan.

a. Aktivitas Guru

Tabel 4. Penigkatan Aktivitas Guru Pada Setiap Siklus

\begin{tabular}{|c|c|c|c|c|c|}
\hline \multirow{2}{*}{ No } & \multicolumn{4}{|c|}{ Aktivitas Siswa } \\
\cline { 2 - 6 } & \multirow{2}{*}{ Prasiklus } & \multicolumn{2}{|c|}{ Siklus I } & \multicolumn{2}{c|}{ Siklus II } \\
\cline { 3 - 6 } & & 1 & 2 & 1 & 2 \\
\hline 1 & 9 & 13 & 14 & 17 & 17 \\
\hline \multirow{2}{*}{ Jumlah } & \multirow{2}{*}{$47,4 \%$} & 68,42 & 73,68 & 89,47 & 89,47 \\
\cline { 3 - 6 } & & \multicolumn{2}{|c|}{$71,05 \%$} & \multicolumn{2}{c|}{$89,47 \%$} \\
\hline
\end{tabular}

Berdasarkan tabel 4 hasil aktivitas guru dalam mengajarkan jenis motif hias dengan model Gallery Walk mengalami peningkatan pada setiap siklusnya, adapun peningkatannya meliputi pra siklus 47,4\% (sedang), siklus I 71,05\% (Baik) dan siklus II 89,47\%\% (Sangat Baik). untuk memperjelas perbandingan hasil observasi guru pada setiap siklusnya dapat dilihat pada grafik berikut ini: 


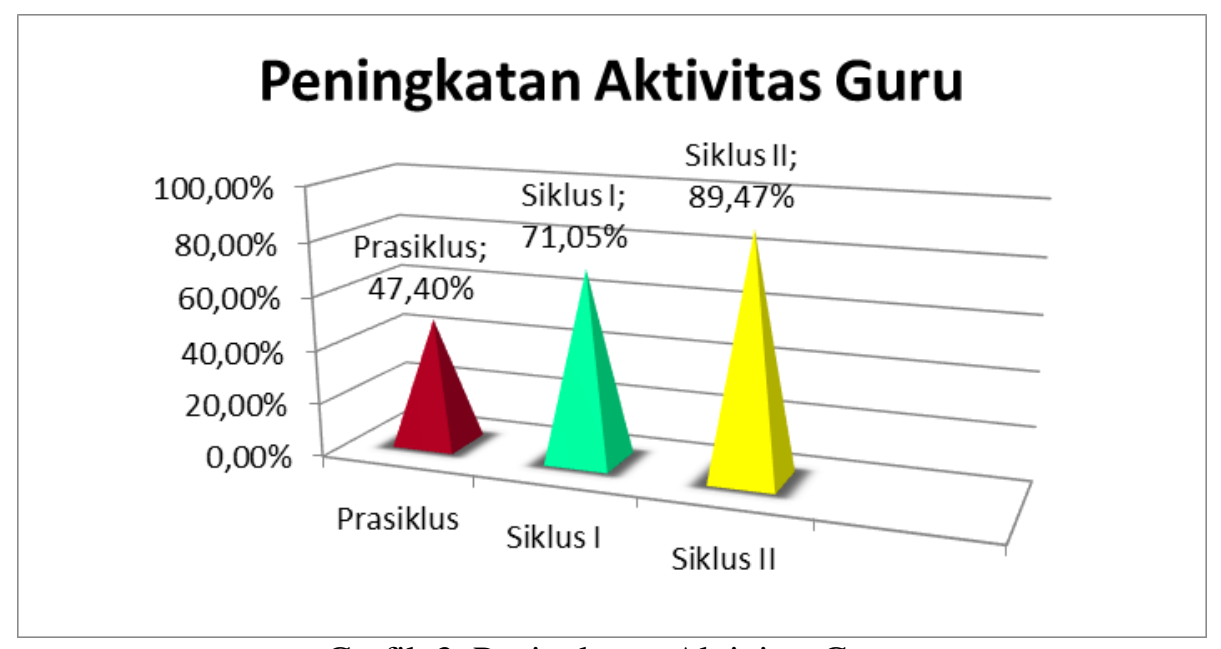

Grafik 3. Peningkatan Aktivitas Guru

Berdasarkan grafik 3 dapat diketahui bahwa hasil observasi aktivitas guru mengalami perbaikan dan peningkatan. Maka dengan adanya peningkatan aktivitas guru pada setiap siklus artinya proses belajar dan mengajar dengan menggunakan model Gallery Walk dapat meningkatkan aktivitas belajar siswa dan guru pada mata pelajaran Seni Budaya dan Keterampilan pokok bahasan jenis motif hias di kelas V MI Al-Manar Kabupaten Cianjur.

\section{KESIMPULAN}

Berdasarkan hasil Penelitian Tindakan Kelas di kelas V MI Al-Manar Kabupaten Bandung dengan menerapkan model Gallery Walk pada mata pelajaran SBK pokok bahasan jenis motif hias, maka diperoleh simpulan sebagai berikut.

1. Aktivitas belajar siswa sebelum menggunakan model Gallery Walk pada mata pelajaran Seni Budaya dan Keterampilan pokok bahasan jenis motif hias di kelas V MI Al-Manar Kabupaten hanya mencapai $28,07 \%$ dengan kategori kurang. Hal ini dilihat dari respon pada observasi awal pada kegiatan penelitian. Terlihat aktivitas siswa kurang antusias dan kurang aktif selama proses pembelajaran berlangsung, siswa cenderung jenuh, kurang semangat dalam kegiatan pembelajaran, malas, dan hal ini mengakibatkan kondisi kelas menjadi kurang kondusif.

2. Penerapan model Gallery Walk pada mata pelajaran Seni Budaya dan Keterampilan pokok bahasan jenis motif hias di kelas V MI Al-Manar Kabupaten Cianjur tergolong aktif. Aktivitas guru pada siklus I mencapai 71,05\% dengan kategori baik dan mengalami peningkatan pada siklus II yaitu sebesar $89,47 \%$ dengan kategori sangat baik.

3. Aktivitas belajar siswa sesudah menggunakan model Gallery Walk pada mata pelajaran Seni Budaya dan Keterampilan pokok bahasan jenis motif hias di kelas V MI Al-Manar Kabupaten Cianjur mengalami peningkatan, yaitu pada siklus I sebesar 62,6\% dengan kategori aktif dan pada siklus II sebesar 83,3\% dengan kategori sangat aktif.

\section{DAFTAR PUSTAKA}

Bandi, dkk. (2009). Pembelajaran Seni Budaya dan Keterampilan. Bandung : Bumi Aksara Hamalik, O. (2011). Proses Belajar Mengajar. Jakarta : PT. Bumi Aksara

Marno dan Idris. (2009). Strategi dan Metode Pengajaran. Jogjakarta : Ar-Ruzz Media

Naisah. (2013). "Pembelajaran Seni Budaya dan Keterampilan Dengan Menggunakan Pendekatan Inkuiri Di Sekolah Dasar". SkripsiSarjana. Pontianak : Fakultas Keguruan dan Ilmu Pendidikan Universitas Tanjungpura Pontianak.

Purwanto, N. (2000). Prinsip-prinsip dan Teknik Evaluasi Pembelajaran. Bandung: PT. Remaja Rosdakarya.

Salahuddin, A. (2015). Penelitian Tindakan Kelas. Bandung : CV Pustaka Setia 
Silberman,Melvin L. 2009. Active Learning : 101 Strategi Pembelajaran Aktif. Yogyakarta Pustaka Insan Madani

Sugiyono. (2012). Metode Penelitian Kuantitatif, Kualitatif, dan R\&D. Bandung : ALFABETA.

Sukmadinata, N. S. (2012). Metode Penelitian Pendidikan. Bandung : PT Remaja Rosdakarya.

Tim Teaching, Pendidikan Pelatihan Profesi Guru (PLPG) LPTK Rayon IAIN Walisongo Semarang”. http://www.scribd.com/doc/41637080/6-aplikasi-PAIKEM-revisi (20 November 2015).

Susilawati, W. (2010). Pendidikan Matematika. Bandung: UIN Bandung.

Uno, Hamzah, dan Nurdin M. (2013). Belajar Dengan Pendekatan PAIKEM : Pembelajaran Aktif, Inovatif, Lingkungan, Kreatif, Efektif, Menarik. Jakarta Bumi kasara

Widarti, S., dkk. (2013). "Pembelajaran Gallery Walk Berpendakatan Contextual Teaching Learning Materi Siistem Penceraan Di SMA". http :// Journal.unnes.ac.id/sju/index.php/ujeb (diunduh tanggal 8 Nopember 2015)

Yahya, M. (2010). Pengantar Pendidikan. Bandung: Solo 